\title{
EKONOMI PANCASILA DAN IMPLIKASINYA DALAM PEMBELAJARAN EKONOMI
}

\author{
Agussalim \\ Agussalimmpd08@gmail.com
}

\begin{abstract}
ABSTRAK
Pancasila dalam konteks ekonomi merupakan ideologi bagi pelaku ekonomi di Indonesia. Ajaranutama ekonomi Pancasila bahwadalam berekonomi semata-mata tidak hanya bermotif memaksimalkan keuntungan (profit) dan kepuasaan (utility) ekonomi; sekalipun rugi secara ekonomi tidak perlu dianggap gagal kalau pada waktu yang bersamaan mendapat kerabat baru (petuah Jawa). Pancasila yang dirumuskan menjadi tiga komponen sistem ekonomi, yaitu: (1) Sila pertama dan dua merupakan dasar atau input: Etika Ketuhanan dan Kemanusiaan; (2) Sila ketiga dan keempat merupakan metode atau proses: Kekeluargaan dan Nasionalisme; dan (3) Sila kelima adalah tujuan atau output: Keadilan Sosial Ekonomi. Upaya untuk mengokohkan paham ekonomi Pancasila salah satunya dengan mengintegrasikan nilai-nilai Pancasila pada setiap kompetensi dan materi pembelajaran ekonomi yang selama ini luput dari pembelajaran di sekolah dan PerguruanTinggi.
\end{abstract}

Kata Kunci: Ekonomi Pancasila, Pembelajaran Ekonomi

\section{PENDAhULUAN}

Pasca reformasi bangsa Indonesia telah mengawali sejarah baru yang penuh dengan kebebasan berekspresi. Kebebasan itu dapat berdampak pada eksistensi kehidupan manusia sebagai homo sosial, homo religius dan homo economicus. Pancasila merupakanpandangan hidup bangsaIndonesia agar senantiasa tumbuh dalam diri sebagai pembimbing interaksi antar individu dan kelompok yang ada. Namun akhir-akhir ini nilai-nilai Pancasila cenderung ditinggalkan dalam praktek kehidupan. Sebagai dampaknya eksistensi bangsa Indoensia yang pluralis pun kini terancam karena kebebasan yang kebablasan. Eksistensi bangsa Indonesia yang pluralistik terancam jika dasar negara dan konstitusi (Pancasila dan UUD 1945) tidak dijadikan ukuran dan acuan dalam berpikir serta berprilaku sebagai warga negara.

Ancaman lain terhadap eksistensi Pancasila adalah dampak negative dari globalisasi. Keberadaan globalisasi menuai pro-kontra, namun harus diakui globalisasi ibarat dua sisi mata uang logam bisa menjadi peluang untuk kemajuan, dan bisa menjadi ancaman terhadap pudarnyanilai-nalaiPancasila. Sebab globalisasi memuat paham individualistik dan pragmatis. Pragmatis merupkan jelmaan dari kapitalisme global ibarat virus yang memudarkan nilai-nilai Pancasila melalui dikembangkannya demokrasi liberal yang melegalkan politik marjinalisasi dan akumulasi pertumbuhan individualistic dan hegomoni ekonomi sehingga meniadakan kesejahteraan social ekonomi yang adil merata.

Selain beberapa ancaman tersebut, politisasi di kalangan elit juga menjadi ancaman tersendiri terhadap eksistensi Pancasila. Hal ini bisa dilihat pada masa rezim Orde Baru dikenal dengansebutanekonomi Pancasila, namun karena Pancasila itu erat hubungannya dengan politik Orde Baru makapasca reformasi para pakar lebih cenderung menyebutnya dengan ekonomi kerakyatan. Pun dalam perjalanannya 16 | Program Studi Pendidikan Ekonomi, Sekolah Tinggi Keguruan dan Ilmu Pendidikan (STKIP) Bima 
ekonomi kerakyatan tidak berjalan sebagaimana mestinya sesuai dengan apa yang dicita-citakan oleh Pancasila dan UUD 1945 Pasal 33 (Soepriyatno, 2008)

Ditinjau dari perspektif ilmu ekonomi, ancaman tersebut menjadi alasan munculnya kekhawatiran karena dengan melihat keterpurukan perekonomian nasional, meningkatnya kejahatan di sektor riil dan non-riil yang semakin mengkhawatikan akan munculnya stigma negatif bahwa ekonomi Pancasila dianggap tidak relevan dengan tuntutan dan tantangan zaman untuk membawa keluar bangsa Indonesia dari lingkaran setan kemiskinan. Oleh karena itu, sudah sepatutnya mengimplementasikan gagasan ekonomi Pancasila dalam segala aspek kehidupan, yaitu dengan menjadikan Pancasila sebagai dasar berekonomi. Dengan kata lain menjadikan Pancasila sebagai rujukan mutlak dalam memecahkan segalapersoalan ekonomi, baik dari segi makromaupun mikro.

Ekonomi Pancasila merupakan aturan main bagi kehidupan ekonomi Indonesia denganmenghubungkan antara pelaku ekonomi yang didasarkan pada nilai-nilai Pancasila. Untuk mengokohkan ekonomi Pancasila, maka harus diinternalisasi kemudian diimplementasikan dalam proses pendidikan dan pembelajaran ekonomi. Ekonomi Pancasila harus diajarkan mulaidaritingkat sekolahagar sejak dini anak bangsa dapat mengenal penampaan ekonomi Pancasila baik secara teoritis maupun dalam bentuk praktiknya. Ini merupakan usaha penaburan benih Pancasila agar kelak anak bangsa ini tidak kehilangan jati dirinya sebagai bangsa Indonesia yang Pancasilais sekaligus sebagai solusi ditengah semakin mengikisnya nilai-nilai moral ekonomidalam kehidupan berbangsa dan bernegara yang disebabkan oleh pertarungan ekonomi global yang terus mewarnai kehidupan ekonomi Indonesia. Selama ini, Pancasila hanya diajarkan secara parsial sebagai sebuah mata pelajaran saja. Seharusnya nilai-nilai Pancasila terintegrasi pada setiap kompetensi dalam mata pelajaran ekonomi sebagaiupayapenguatan pola pikir, sikap, dan pola tindak anakbangsayang sesuai denganideologi Pancasiladan UUD 1945.

Selamaini menurut Mubyarto (2004) homo-economicus ala kapitalis barat yang bermotifkan hanya memaksimalkan keuntungan (profit) dan kepuasaan (utility) atas barang dan jasa yang terbatas, sayangnya pertama-tama telah diajarkan di sekolah.Wahjoedi (2015) menyebutkanbahwapendidikanekonomi di Indonesia yang didambakan untuk menjadikan anak bangsa sebagai sumber daya manusia pelaku ekonomi yang bangga untuk mengamalkan nilai-nilai ekonomi berlandaskan pada ideology Pancasila dan UUD 1945, namun dalam kenyataanya pendidikan ekonomi kita malah menjauhkan anak bangsa Indonesia sendiri dari karakter nilai-nilai dasar ekonomi Pancasila.

Berdasarkan uraian di atas, maka dipandang penting untuk merumuskan “Ekonomi Pancasila dan Implikasinya dalam Pembelajaran Ekonomi”. Gagasan ini diharapkan dapat dikembangkan untuk diterapkan dalam pembelajaran ekonomi mulai dari sekolah dasar sampai pada perguruan tinggi.

\section{II.PEMBAHASAN}

\section{Konsep Ekonomi Pancasila}

Sri-Edi Swasono(2008) menyebut bahwa ekonomi Pancasila adalah paradigma baru ilmu ekonomi, dengan konsep baru cooperation, cooperatives, planning, grassroots di dalamnya, yang sulit ditemui bahkan tidak ada dalam ilmu ekonomi

\section{7 | Program Studi Pendidikan Ekonomi, Sekolah Tinggi Keguruan dan Ilmu Pendidikan (STKIP) Bima}


konvensional. Lebih lanjut, diakuinya dimensi ilmu ekonomi sebagai ilmu moral, sebagaimana pula diyakini kaum strukturalis tentulah pula menyentuh nilai-nilai agama. Atau ekonomi Pancasila sebagai sistem ekonomi pasar yang terkelola dan kendali pengelolaannya adalah nilai-nilai Pancasila yang berbeda dengan teori ekonomi neoklasik yang dibangun atas dasar paham liberal mengedepankan nilai individualisme dan kebebasan pasar.

Jadi dapat dipahami bahwa ekonomi Pancasila merupakan sistem perekonomian yang orientasinya pada keterlibatan orang banyak dalam aktivitas ekonomi, dengan mengacu pada nilai-nilai yang digali dari falsafah Pancasila, atau ekonomi Pancasila adalah aturan main bagi kehidupan ekonomi atau hubungan antara para pelaku ekonomi yang didasarkan pada sila-sila Pancasila.

\section{Sejarah Ekonomi Pancasila}

Ekonomi Pancasila merupakan sistem ekonomi yang oleh pelaku ekonomi harus berlandaskan dan menjiwai nilai-nilai yang terkandung dalam Pancasila. Ekonomi Pancasila merupakan operasionalisasi dari ide-ide Bung Hatta. Istilah ekonomi Pancasila kali pertama digunakan oleh Dr. Emil Salim pada tahun 1967 dalam suatu artikelnya. Istilah itu menjadi lebih jelas ketika pada tahun 1979, karena Emil Salim membahas kembali apa yang dimaksud dengan ekonomi pancasila. Pada pokoknya ekonomi Pancasila adalah suatu konsep kebijaksanaan ekonomi, setelah mengalami pergerakan seperti bandul jam dari kiri ke kanan, hingga mencapai titik keseimbangan. Kekanan artinya bebas mengikuti aturan pasar, sedangkan ke kiri artinya mengalami intervensi negara dalam bentuk perencanaan memusat. Secara sederhana ekonomi Pancasila dapat disebut sebagai sebuah sistem ekonomi pasar dengan pengendalian pemerintah atau ekonomi pasar terkendali. Ada istilah-istilah lain yang mendekati pengertian ekonomi Pancasila yaitu ekonomi campuran maksudnya campuran antara sistem kapitalisme dan sosialisme atau sistem ekonomi jalan ketiga. Tetapi kedua istilah itu banyak variasinya di dunia.

Menurut Sri-Edi Swasono (2008) Mubyarto yang lebih substansial memahami ekonomi pancasila (konsep, sistem, aktivitas, filsafat ilmu), sementara Emil Salim menekankan pada sistem (kebijakan) semata, yang terkesan politis cenderung akomodatif terhadap teori konvensional (konsep, sistem filsafat ilmu). Namun harus dicatat, Mubyarto-lah pada tahun 1981 yang membawa wacana ekonomi Pancasila dalam diskusi ilmiah dan perkuliahan di perguruan tinggi di Indonesia. Ekonomi Pancasila dilahirkan dalam suasana perang/kontradiksi dalam tubuh ideologi materialism dan menegaskan supremasi moral dan nilai transenden (agama). Kapitalisme, sebagai senyawa materialisme yang terlalu berlandaskan pada maksimisasi kepuasan kebendaan dan kepentingan pribadi, homo economicus, kurang memerhatikan kesejahteraan manusia dan kepentingan sosial. Ekonomi Pancasila dirumuskan berdasar asas kebersamaan dan kekeluargaan, berbasis pada ideologi Pancasila dan UUD 45, di mana dalam pancasila tersebut manusia mencari keseimbangan antara hidup sebagai pribadi, dan hidup sebagai anggota masyarakat.

18 | Program Studi Pendidikan Ekonomi, Sekolah Tinggi Keguruan dan Ilmu Pendidikan (STKIP) Bima 


\section{Prinsip Ekonomi Pancasila}

Prinsip Ekonomi Pancasila merujuk pada Pembukaan Undang-Undang Dasar Tahun 1945, bahwa tujuan berbangsa dan bernegara adalah untuk: (a) Melindungi segenap bangsa Indonesia dan seluruh tumpah darah Indonesia; (b) Memajukan kesejahteraan umum; (c) Mencerdaskan kehidupan bangsa, dan (d) Ikut melaksanakan ketertiban dunia berdasarkan kemerdekaan, perdamaian abadi dan keadilan sosial. Lebih lanjut dalam Pasal 33 UUD 1945 memuat beberapa prinsip ekonomi, yaitu: (a) Perekonomian disusun sebagai usaha bersama atas asas kekeluargaan; (b) Cabang-cabang produksi yang menguasai hajad hidup orang banyak dikuasai oleh Negara; (c) Bumi, air dan kekayaan alam yang terkandung didalamnya dikuasai oleh negara dan dipergunakan sebesar-besanya untuk kesejahteraan rakyat; dan (d) Perekonomian nasional diselenggarakan berdasar atas demokrasi ekonomi dengan prinsip kebersamaan, efisiensi berkeadilan, berkelanjutan, berwawasan lingkungan, kemandirian, serta dengan menjaga keseimbangan kemajuan dan kesatuan ekonomi nasional.

\section{Internalisasi Ekonomi Pancasila}

Internalisasi nilai-nilai Pancasila dalam perspektif sistem ekonomi, yaitu dengan merumuskan sila-sila Pancasila menjadi sebuah komponen sistem, meliputi: (1) Dasar atau in-put: Etika Ketuhanan dan Kemanusiaan; (2) Metode atau proses: Kekeluargaan dan Nasionalisme; dan (3) Tujuan atau out-put: Keadilan Sosial Ekonomi. Doktrin ekonomi pancasila memberi pemenekanan bagi setiap pelaku ekonomi agar segala aktivitas ekonomi memperhatikan nilai ketuhanan dan kemanusiaan yang merupakan dasar/input dari ajaran ekonomi Pancasila. Setelah dasarnya kokoh, selanjutnya cara/proses kerja ekonomi Pancasila adalah dengan mengedepankan asas kekeluargaan melalui demokrasi ekonomi yang dijawai dengan semangat nasionalisme. Jika cara ini telah berkerja dengan baik maka keadilan sosial ekonomi yang merupakan tujuan/ouput ekonomi Pancasila akan dapat diwujudkan dalam kehidupan berbangsa dan bernegara.

Ditinjau dari segi motif, ekonomi Pancasila bukan hanya motif memaksimalkan keuntungan (profit) dan kepuasaan (utility) ekonomi semata, tetapi juga menyangkut motif agama, sosial dan budaya. Pun motif ekonomi, ekonomi Pancasila mengajarkan sifat akomodatif, yaitu mengakomodasikan keseimbangan ekonomi sacara bersama-sama dan kepentingan ekonomi secara individu; kemandirian dalam kebersamaan guna membangun, mempercepat dan memperkokoh pertumbuhan perekonomian. Menurut Murbyarto (2004) dalam ekonomi Pancasila tidak sematamata bermotif memaksimalkan kepuasaan ekonomi; rugi tidak perlu dianggap gagal kalau pada waktu yang bersamaan mendapat kerabat baru. Untuk lebih jelas dan mudah dipahami penampaan ekonomi Pacasila, selanjutnya dibuat konseptualisasi sebagai berikut. 


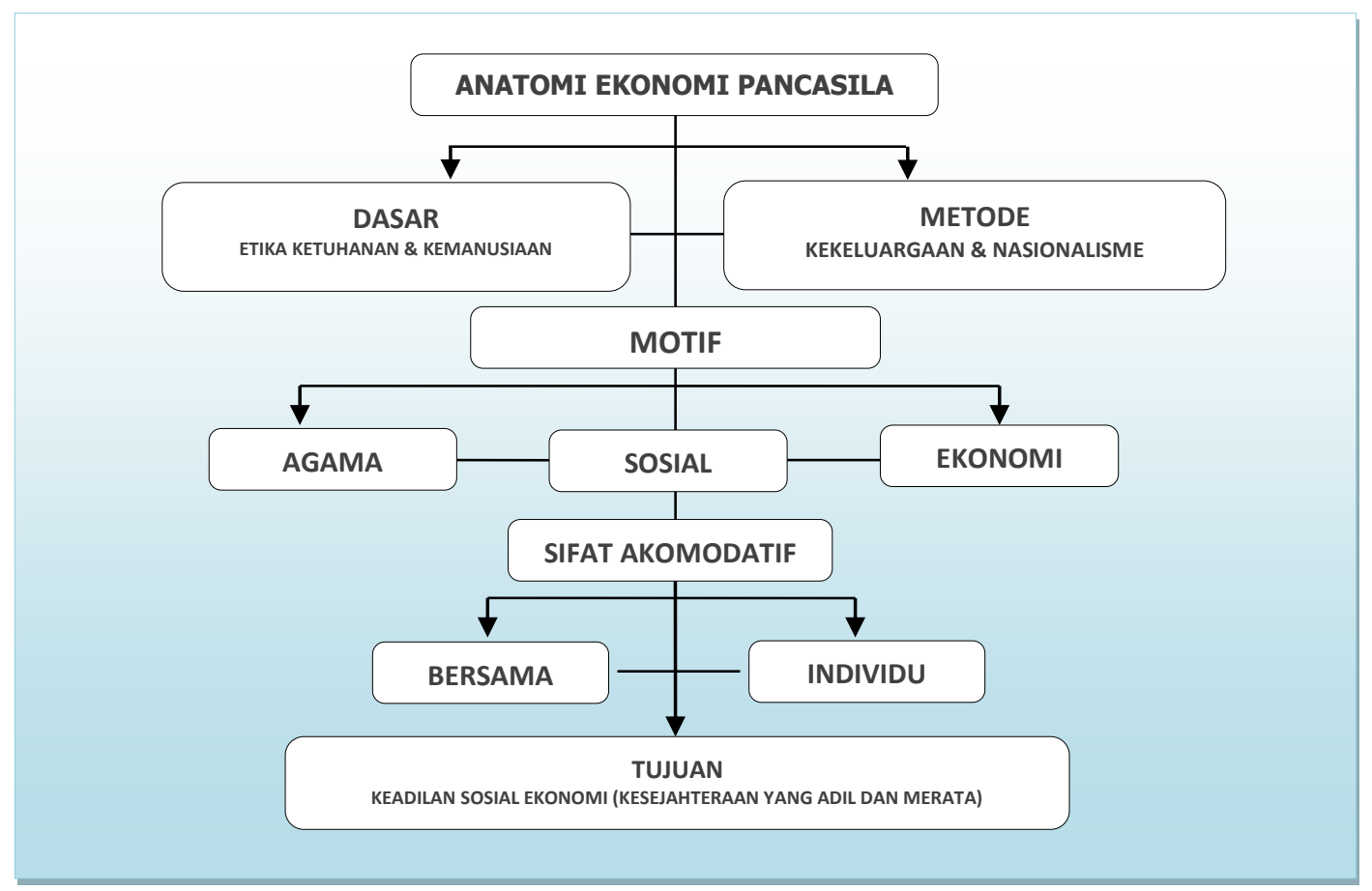

Merujuk pada anatomi ekonomi Pancasiladi atas, selanjutnya dapat diinternalisasi darimasing-masing komponen sistem sebagai berikut.

\section{Dasar Ekonomi Pancasila}

Di era krisis moral ini sudah sepatutnya kita berintropeksi diri dan kembali mengenang serta menjunjung tinggi nilai etika ketuhanan dan kemanusiaan dalam bersikap, berpikir, dan bertindak sebagai mahluk ekonomi (homo economicus) agar dalam praktek ekonomi tidak mengabaikan nilai agama, sosial dan budaya. Menurut Nirbito (2005) prilaku dunia bisnis yang hampa kandungan nilai mengakibatkan terjadinya ancaman instabilitas sosial sehingga kedamaian hidup menjadi maya.

Secara teoritis, bahwa etika adalah salah satu cabang ilmu filsafat yang secara eksplisit mendalami konsep moralitas. Menurut Syaiful Sagala (2011) etika pada hakikatnya mengamati realitas moral secara kritis dan tidak memberi ajaran melainkan memeriksa kebiasaan-kebiasaan, nilai-nilai, norma-norma, serta pandangan-pandangan moral secara kritis. Senada dengan itu, Darmayanti Lubis (2011) menjelaskan bahwa etika erat kaitannya dengan moralitas, hubungan antara manusia dan kemanusiaan dapat bersumber baik dari ajaran agama, budaya, bangsa, maupun dari keteladanan terhadap perilaku seseorang.

Jadi, dapat disimpulkan bahwa etika ketuhanan dan kemanusiaan merupakan perilaku yang bermoral terhadap Tuhan dan sesama manusia. Etika ketuhanan dan kemanusia bukan dalam konteks pengajaran, melainkan pada perbuatan nyata seperti menjunjung tinggi perintah dan larangan Tuhan Yang Maha Esa dan kepedulian terhadap sesama manusia yang bersumber dari ajaran agama, budaya dan 
keteladanan sesorang, sehingga kedudukan etika ketuhanan dan kemanusiaan merupakan dasar segala aktivitas ekonomi.

Kegiatan produksi, distribusi dan konsumsi merupakan garis besar aktivitas ekonomi dan ketiga aktivitas ekonomi tersebut memiliki motif memaksimalkan keuntungan (profit) dan kepuasaan (utility). Oleh karena itu, usaha memaksimalkan keuntungan maupun kepuasaan harus memperhatikan etika ketuhanan dan kemanusiaan, yang meliputi: Pertama, memperhatikan ajaran agama dengan kata lain, apakah barang dan jasa yang diproduksi, didistribusi dan dikonsumsi bertentangan atau tidak dengan ajaran Tuhan. Contohnya, memproduksi, mendisribusi dan mengkonsumsi barang yang tergolong haram misalnya narkotika dan obat-obatan terlarang (narkoba), minuma keras (miras), atau jenis barang dan jasa lain yang memiliki nilai mudoratnya lebih tinggi daripada manfaatnya karena dalam konteks nilai kemanusiaan dapat merugikan diri sendiri dan orang lain. Mengkonsumsi barang haram yang mengakibatkan pengguna dalam keadaan tidak normal secara psikologis (mabuk) yang ditandai dengan hilangnya rasa takut dan rasa malu sementara hakikat rasa itu dalam konteks kebaikan merupakan unsur pembeda antara manusia dan hewan. Di sektor moneter, di masyarakat kerap sekali terjadi berupa kegiatan rentenir. Rentenir merupakan konsep pinjaman dengan kesepakatan agar si peminjam membayar plus bunga pinjaman bahkan bunga berbunga. Jauh sebelumnya Plato (427-347 SM) yang dikutip oleh Deliarnov (2012) bahwa uang itu bersifat mandul, tidak dapat sekaligus tidak layak untuk dikembangkan atau peranakan. Sedangkan dalam ajaran Islam perbuatan demikian disebutkan dengan perbuatan syaitan (Al-Baqarah).

Kedua, keyakinan selalu diawasi oleh Tuhan. Dalam keadaan tertutup (sembunyi) dari pengawasan orang lain, sebagai manusia yang ber-Tuhan kita wajib meyakini dengan sepenuh hati bahwa Tuhan itu Maha Tahu, sehingga merasa selalu diawasi oleh Tuhan kapan dan di manapu berada. Pemalsuan uang, kecurangan timbangan, korupsi yang kerap terjadi dalam kehidupan adalah sebagian kecil dari sekian banyak kasus yang relatif susah diketahui secara langsung oleh penega hukum. Oleh karena itu harus ada kesadaran bagi setiap pelaku ekonomi bahwa Tuhan selalu mengawasi setiap aktivitas kita.

Ketiga, keyakinan adanya ganjaran Tuhan. Segala bentuk aktivitas ekonomi yang bertentangan dan/atau sesuai dengan ajaran Tuhan pasti akan mendapat imbalan atau ganjaran yang setimpal dari Tuhan, baik di dunia maupun di akhirat. Kita dapat menyaksikan bagaimana nasib koruptor dan pengedar misalnya, berakhir di penjarah bahkan "sampai mati". Belum lagi ganjaran yang akan didapatkannya kelak di akhirat.

Berdasarkan hasil internalisasi dasar ekonomi Pancasila di atas, dapat disimpulkan bahwa terdapat rangkaian sistem (hubungan) antara etika ketuhanan dengan kemanusiaan. Pola hubungannya adalah mereprestasikan hubungan manusia 
dengan Tuhan dan hubungan manusia dengan sesama manusia. "Jika adanya pengabaian etika ketuhanan, pada yang waktu bersamaan berpotensi terjadinya pelanggaran nilai kemanusiaan; jika manusia tidak aktif dalam kegiatan ritual keagamaan memungkinkan sekali manusia akan tidak memperhatikan nilai kemanusiaan terhadap diri dan orang lain". Untuk lebih jelasnya, selanjutnya dikonseptualisasikan dalam bentuk kurva sebagai berikut.

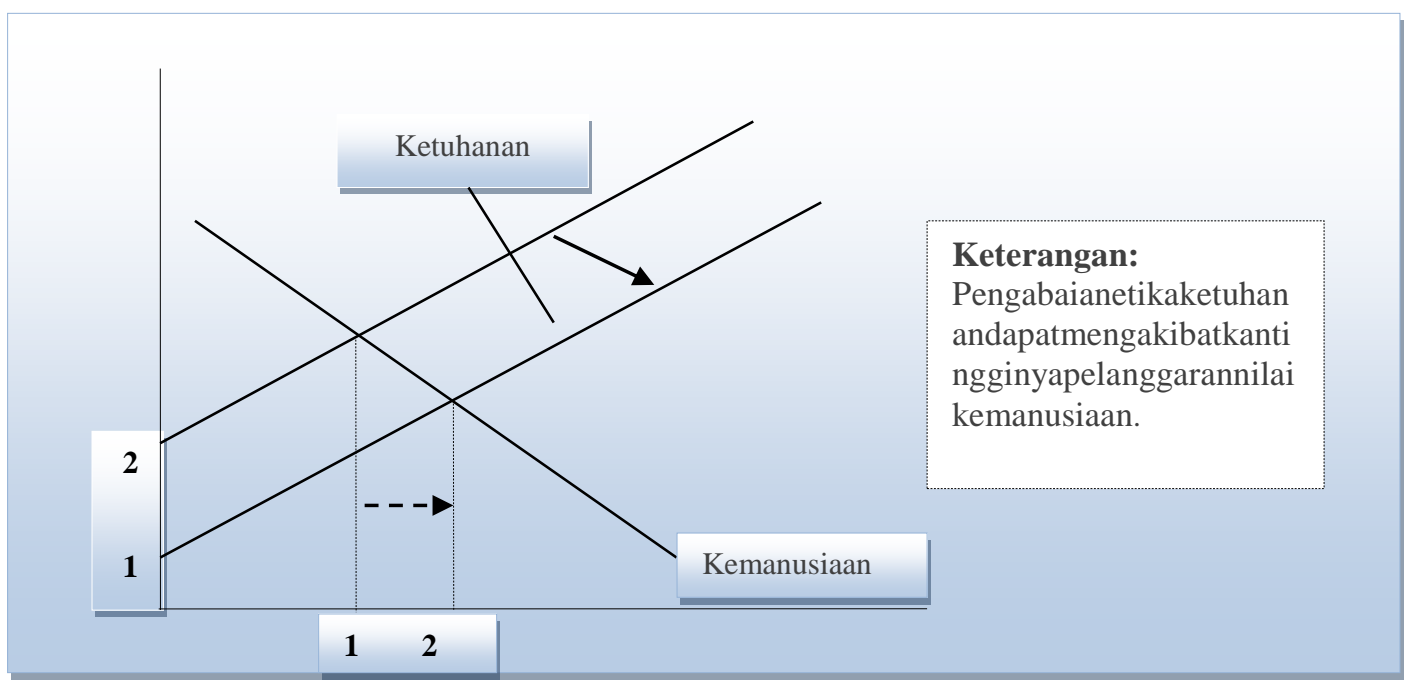

\section{Metode Ekonomi Pancasila}

Seperti yang tercantum dalam UUD 1945 Pasal 33 ayat 1 disebutkan bahwa "Perekonomian disusun sebagai usaha bersama atas asas kekelurgaan". Kata asas kekeluargaan terkadang dipleset ketika menyindir kebijaksanaan ekonomi yang lebih mengutamakan pihak keluarganya dan kelompok tertentu. Hakikat asas kekeluargaan mencerminkan bahwa setiap pelaku ekonomi dan jalur perekonomian nasional hubungganya ibaratkan satu rumah tangga keluarga. Urgensi asas kekeluargaan mengingat di Indonesia memiliki dua jalur perekonomian, yaitu:

Pertama, jalur ekonomi kerakyatan, mencakup: (1) Koperasi adalah perkumpulan otonom dari orang-perorang yang bersatu secara sukarela untuk memenuhi kebutuhan-kebutuhan dan aspirasi ekonomi, sosial dan budaya bersama melalui perusahaan yang dimiliki bersama dan dikendalikan secara demokratis. Koperasi yang didasari pada UU No. 25 Tahun 1992 merupakan cerminan jati diri (soko guru) perekonomian nasional terlepas dari isu bahwa itu hanya wacana belaka. (2) Usaha Mikro Kecil dan Menengah (UMKM) yang dipayungi oleh UU No. 20 Tahun 2008 merupakan jalur ekonomi kerakyatan yang paling banyak di Indonesia dan sudah terbukti kokoh dalam menghadapi terpaan kiris global yang melanda bangsa ini khususnya tahun 1997/1998. Juga UMKM memiliki peranan strategi terhadap kekuatan ekonomi nasional yang ditandai dengan potensi besar dalam penyerapan tenaga kerja domestik.

Kedua, Jalur ekonomi Koorporasi, meliputi: (1) Badan Usaha Milik Negara (BUMN) adalah badan usaha yang sebagian atau seluruh kepemilikannya dimiliki oleh Negara Republik Indonesia. BUMN dapat pula berupa perusahaan nirlaba yang bertujuan untuk menyediakan barang atau jasa bagi publik. BUMN dipayungi oleh UU No. 19 Tahun 2003. Isu BUMN cenderung inefisiensi karena dapat disebabkan 22 | Program Studi Pendidikan Ekonomi, Sekolah Tinggi Keguruan dan Ilmu Pendidikan (STKIP) Bima 
adanya praktek KKN dan rendahnya SDM sebagai pengelola (Nirbito, 2005). (2) Badan Usaha Milik Swasta (BUMS) adalah badan usaha yang seluruh modalnya berasal dari pihak swasta yang dimiliki seseorang atau beberapa orang yang bertujuan untuk mencari keuntungan seoptimal mungkin untuk mengembangkan usaha dan modalnya serta membuka lapangan pekerjaan. Selain berperan dalam menyediakan barang dan jasa, badan usaha milik swasta juga membantu pemerintah dalam usaha mengurangi pengangguran serta memberi kontribusi dalam pemasukkan dana berupa pajak. BUMS dipayungi oleh UU No 40 Tahun 2007 dan Isu BUMS cenderung tamak dikarenakan efisiensi sehingga mengabaikan tanggung jawab sosial dan lingkungan.

Demi kebangkitan perekonomian nasional, kedua jalur ekonomi tersebut harus membangun gerakan kemitraan yang merupakan implementasi dari asas kekeluargaandanpemerintah sebagai motor penggerak. Peranan pemerintah dalam gerakan kekeluargaan melalui kemitraan yang paling utama adalah: Pertama, menciptakan iklim usaha yang sehat bagi kemitraan usaha kemudian pemerintah memberikan pedoman tentang kemitraan melalui peraturan perundangan seperti seperti UU No. 5 Tahun 1999 tentang Larangan Praktek Monopoli dan Persaingan Usaha Tidak Sehat melalui Komisi Pengawas Persaingan Usaha Republik Indonesia. Kedua. memberi informasi dan peluang kemitraan serta teknis dalam perencanaan kemitraan. Gerakan kemitraan perlu mempertemukan antara konsep dan implementasi kemitraan dilapangan dengan cara: (a) pelaksanaan kemitraan berdasarkan pada strategi dasar yaitu hubungan kemitraan yang memiliki keterkaitan usaha, kemitraan yang tidak memiliki keterkaitan usaha, dan penciptaan pelaku bisnis baru; (b) implementasi gerakan kemitraan dengan langkah-langkah penetapan komitmen kemitraan dan identifikasi peluang kemitraan oleh pemilik usaha, sosialisasi program kemitraan usaha, publikasi program dan hasil-hasil kemitraan dan monitoring pelaksanaan kemitraan; dan (c) perlu memikirkan sasaran gerakan kemitraan yaitu dunia usaha secara keseluruhan.

Pengembangan gerakan kekeluargaan melalui kemitraan antara pelaku ekonomi dapat dilakukan dalam berbagai pola, seperti peningkatan kualitas dan kapasitas usaha, perencanaan, dan promosi produk serta permodalan bagi jalur ekonomi kerakyatan yang intinya diarahkan untuk pengembangan koperasi dan UMKM sebagai pelaku ekonomi jalur ekonomi kerakyatan. Melalui gerakan kekelurgaan diharapkan dapat memberdayakan jalur ekonomi kerakyatan yang berorientasi menciptakan pemerataan dan bagi pelaku ekonomi koorporasi dapat mempercepat dan mempertinggi pertunbuhan perekonomian nasional. Jadi prinsipnya adalah saling memerlukan, memperkuat dan menguntungkan. Urgensi gerakan kekeluargaan melalui kemitraan menurut Nirbito (2005) salah satu kunci kesuksesan ekonomi negara maju adalah melalui sistem kemitraan usaha yang didorong oleh adanya keterkaitan kebutuhan dari pihak-pihak yang bermitra kemudian diprakarsai oleh pelaku dunia bisnis itu sendiri sehingga kemitraan dapat berlangsung secara alamiah.

Asas kekelurgaan, hakikatnya merupakan jatidiri bangsa Indoensia. Asas kekeluargaan belum cukup untuk menjamin kemajuan ekonomi tanpa adanya semangat nasionalisme di tengahgencarnyakampanyeasingnisasi. Nasionalisme merupakan kesadaran keanggotaan dalam suatu bangsa yang secara potensial atau

\section{3 | Program Studi Pendidikan Ekanomi, Sekolah Tinggi Keguruan dan Ilmu Pendidikan (STKIP) Bima}


aktual bersama-sama mencapai, mempertahankan, dan mengabadikan identitas, integritas, kemakmuran, dan kekuatan bangsa itu, yakni semangat kebangsaan. Nasionalisme dapat dirumuskan sebagai satu paham yang menciptakan dan mempertahankan kedaulatan sebuah negara (nation) dengan mewujudkan satu identitas yang dimiliki sebagai ikatan barsama dalam satu kelompok (Depdikbud, 1997).

Semangat nasionalisme jauh lebih dahsyat daripada ledakan boom atom yang telah menghancurkan kota Nagasaki dan Hiroshima. Pernyataan Lean Greefeld (2001) yang dikutip Soepriyatno (2008) bahwa ciri-ciri pertumbuhan yang berkesenambungan dari suatu perekonomian modern ternyata tidak berlangsung secara berkesenambungan, akan tetapi pertumbuhan ekonomi hanya akan berkesenambungan justru jika ditopang oleh nasionalisme.

Ditinjau dari ekonomi internasional bahwa nasionalisme rakyat Indonesia mengalami penurunan, yang ditandai bahwa hampir setiap tahun bangsa Indonesia mengalami devisit neraca transaksi. Demikian bukan semata-mata karena mengimpor barang atau jasa yang tidak dapat diproduksi oleh bangsa sendiri, tetapi pelaku ekonomi Indonesia terkesan lebih cenderung menghargai bahkan bangga terhadap produk bangsa lain. Sebagai efeknya, dalam konteks moneter menjadi salah satu penyebab nilai kurs rupiah cenderung melemah terhadap mata uang asing umumnya terhadap dolar (\$). Secara teoritis bahwa semakin tinggi konsumsi barangdan jasa impor, semakin tinggi pula kebutuhan akan valuta asing (valas) "permintaan mata uang asing akan meningkat” sehingga akan menyebabkan melemahnya (depresiasi) nilai tukat rupiah. Inilah satu penyebab melemahnya keunggula dan kewibawaan ekonomi nasional dalam perspektif moneter di bandingkan dengan negara lain. Oleh karena itu sudah sepatutnya kita lebih mengutamakan dan mencitai produk dalam negeri (domestic) sebagai bentuk kepedulian kita terhadap karya anak bangsa.

Dampak positif jika mencitai produk domestic atau local akan memacu pertumbuhan sector ekonomi kerakyatan yang berimbas pada penciptaan lapangan kerja secara berkelanjutan. Dengan demikian orang Indonesia tidak akan menjadi buruh dan pembantu rumah tangga di negara lain. Ini yang belum terpikirkan dan disadari oleh sebagian besar masyarakat Indonesia dampak negative memudarnya nasionalisme dalam berekonomi. Lebih jelasnya tentang penampaan azas kekeluargaan dan semangat nasionalisme dalam berekonomi, akan dibuat model konseptualisasi ekonomi Pancasila sebagai berikut. 


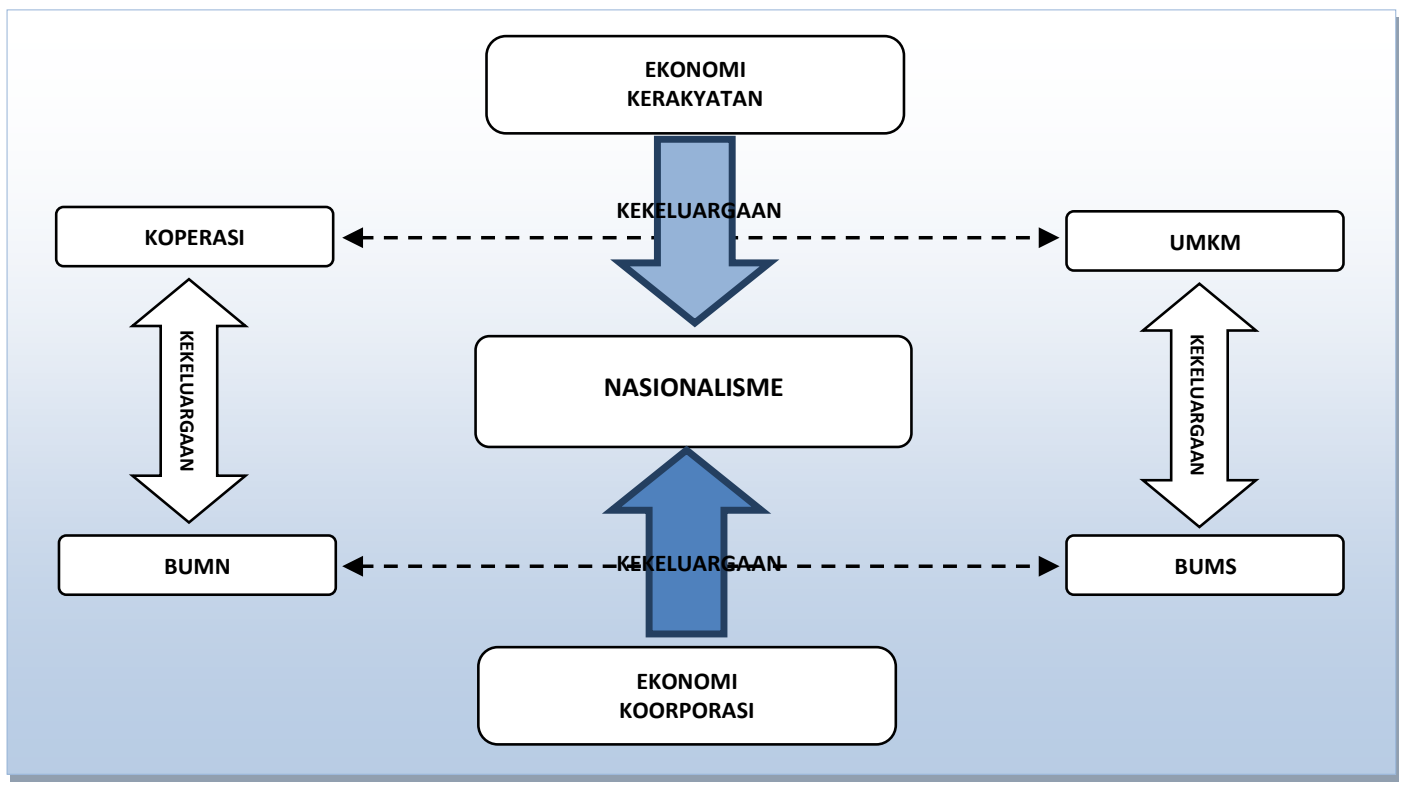

\section{Tujuan Ekonomi Pancasila}

Ajaran ekonomi konvensional bahwa produsen bermotif memaksimalkan keuntungan dengan modal yang kecil dan konsumen bermotif memaksimalkan kepuasaan dengan biaya yang rendah. Kondisi semacam ini menunjukan adanya tarik-menarik kepentingan kedua pelaku ekonomi dan untuk mengimbanginya dibutuhkan keadilan sosial ekonomi. Secara umum, keadilan sosial ekonomi merupakan perilaku yang patuh terhadap norma-norma atau hukum yang berfungsi untuk mencapai kesejahteraan yang adil dan merata bagi seluruh pelaku ekonomi (bukan saja untuk kesejahteraan individu semata melainkan juga untuk kesejahteraan bersama). Untuk memahami perilaku adil atau tidak adil diperlukan unit analisis yang komprehensif.

Analogi kasuistik, jika pengusaha membayar upah buruh di bawah ketentuan Upah Minimum Regional (UMR) adalah suatu pelanggaran, namun tindakan tersebut belum tentu mencerminkan ketidakadilan apabila kemampuan perusahaan untuk membayar memang terbatas yang disebabkan kepailitan. Sebaliknya, pengusaha membayar upah buruhnya sesuai dengan UMR, yang berarti bukan pelanggaran. Justru bisa saja menimbulkan ketidakadilan jika keuntungan pengusaha mengalami surplus dikarenakan produktivitas kerja buruh yang meningkat akan tetapi tidak disertai dengan peningkatan upah yang diterima.

Skala pengukuran ketidakadilan dapat dintinjau dari ketimpangan distribusi pendapatan. Berkenaan dengan itu, hasil survei Bank Dunia (Word Bank) tahun 2014, bahwa ketimpangan di Indonesia semakin meningkat karena sebagian besar pertumbuhan ekonomi hanya dinikmati segelintir orang. Tahun 2003 hingga 2010, dimna 10 persen rumah tangga terkaya di Indonesia menambah konsumsi sebesar 6 persen per-tahun, bagian 40 persen masyarakat rumah tangga miskin, tingkat konsumsi mereka berkurang dari 2 persen per-tahun sehingga mengakibatkan koefisien Gini naik pesat, yaitu dari 30 persen pada tahun 2000 menjadi 41 persen pada tahun 2013. Lebih lanjut hasil survei tersebut mengungkapan bahwa terjadinya ketimpangan atau ketidakadilan sosial ekonomi disebabkan: Pertama, ketimpangan 
peluang, tidak semua orang dapat mengembangkan keterampilan yang diperlukan untuk mendapatkan pekerjaan berupah tinggi. Kedua, dengan semakin besarnya tuntutan untuk memiliki keterampilan yang tepat dalam ekonomi modern, imbalan bagi mereka yang berhasil mendapatkan pekerjaan bagus semakin tinggi. Sementara yang tidak memiliki keterampilan yang dibutuhkan, terjebak dalam pekerjaan dengan produktivitas dan upah rendah. Ketiga, guncangan ekonomi global dapat memengaruhi ketimpangan pada tahap mana pun dalam kerangka ini dengan cara mengikis kemampuan rumah tangga.

Untuk meminimalisir ketidakadilan ekonomi sebagaimana laporan Bank Dunia di atas, dibutuhkan peran penting pemerintah (makro) dan dari setiap pelaku ekonomi (mikro). Secara makro merujuk pada teori keadilan yang bersifat umum. Keadilan secara umum lebih menekan adanya hubungan individu-individu danpemerintah. Demi mewujudkan keadilan ekonomi secara umum perlu dimotori oleh negara atau pemerintah melalui seperangkat kebijakan: Pertama, memperbaiki dan pemerataan pelayanan berkelanjutan seperti sarana dan prasaran publik. Kedua, kebijakan pendidikan melalui adanya beasiswa agar meningkatkan pemerataan keterampilan dan produktivitas kerja. Ketiga, perekrutan tenaga kerjayang transparansi. Keempat, menjamin adanya kesetaraan standar kualiatas/mutu dalam segala aspek dari Sabang sampai Maraoke. Kelima, komitmen penegakan kukum yang berkeadilan, dan kelima politisi yang amah dalam menjalankan fungsinya sebagai representasi rakyat. Berkenaan dengan itu menurut Bertens (2000), negara atau pemerintah harus membagi segalanya dengan cara yang sama kepada para anggota masyarakat. Konkritnya, dalam aspek sosial ekonomi adalah memberikan kesempatan yang sama bagi semua warga untuk mendapatkan pendidikan yang baik, pekerjaan dengan pendapatan yang baik atau kehidupan layak; "ketidakadilan muncul apabila pemerintah mengistimewakan orang-orang tertentu, seperti misalnya dalam mendapatkan proyek-proyek pembangunan".

Keadilan sosial ekonomi secara khusus (mikro) berkaitan dengan keadilan antara para pelaku ekonomi yang tercermin pada kesadaran masing-masing pelaku ekonomi akan pentingya rasa tanggung jawab sosial dan agama terhadap pelaku ekonomi lainnya. Oleh karena itu, menunbuhkan secara terus menerus semangat menjauhi keserakahan-eksploitasi adalah hal utama yang harus disadari dan diwujudkan dalam bentuk perbuatan nyata bagi seluruh pelaku ekonomi di Indonesia.

\section{ImplikasiEkonomiPancasiladalamPembelajaranEkonomi}

Penerapanekonomi Pancasila dalam pembelajaran ekonomi menjadi hal mutlak untuk dilakukan dengan cara mengintegrasika nilai-nilai ekonomi Pancasila pada setiap kompetensi pembelajaran. Demikian selama ini luput dari penerapan pembelajaran di sekolah. Menurut Mubyarto (2004) homo-economicus ala kapitalis barat yang bermotifkan hanya memaksimalkan keuntungan (profit) dan kepuasaan (utility) atas barang dan jasa yang terbatas, sayangnya pertama-tama telah diajarkan di sekolah. Menurut Wahjoedi (2015) pendidikan dan pembelajaran ekonomi di Indonesia yang selama ini didambakan untuk menjadikan anak didik bangsa sebagai SDM pelaku ekonomi yang harus bangga untuk mengamalkan nilai-nilai ekonomi berlandaskan pada ideology Pancasila dan UUD 1945, dalam kenyataanya malah menjauhkan anak bangsa Indonesia sendiri dari karakter nilai-nilai dasar ekonomi Indonesia. Kemudian Mubyarto (2004) menilai bahwa sangat sedikit sarjana

\section{6 | Program Studi Pendidikan Ekonomi, Sekolah Tinggi Keguruan dan Ilmu Pendidikan (STKIP) Bima}


ekonomi di Indonesia yang menyadari kekeliruan bahwa hanya mengenal Adam Smith sebagai bapak Ilmu Ekonomi dunia melalui The Wealth of Natioan (1776), jauh sebelum itu Smith menulis buku pertama The Theory of Sentiment (1759). Akibatnya gagasan perekononian perseorangan (kapitalis) diajarkan pada generasi bangsa sejak masuk di sekolah menengah, padahal sekolah adalah lembanga pendidikan formal yang mempunyai fungsi tidak hanya sekedar transfer of knowledge tetapi juga sebagai transfer of values. Values yang dimaksud dalam ilmu ekonomi adalah pewarisan nilai ekonomi pancasila melalui pembelajaran ekonomi.

Ekonomi Pancasila merupakan sistem ekonomi yang secara esensi bertujuan untuk mengangkat derajat kemanusiaan melalui pemecahan masalah pokok perekonomian. Untuk kepentingan itu maka pembelajaran ekonomi berwawasan Pancasila harusditerapkan sebagai program berkelanjutan agar anak bangsa kelak menjadi pelaku ekonomi senantiasa memperdulikan nilai-nilai pancasila dan menjadikannya sebagai kepribadiannya dalam berekonomi. Jadi, Implikasi sistem ekonomi pancasila dalam pembelajaran ekonomi adalah dengan memasukan nilainilai Pancasila pada setiap kompetensi. Artinya tidak merubah kaidah ilmu ekonomi akan tetapi lebihmenekan padaintegrasietika ketuhanan-kemanusia, kekeluargaannasionalisme dan keadilan sosial ekonomi pada kompetensi mata pelajaran ekonomi.

Mengintegrasikan nilai-nilai Pancasila pada setiap kompetensi pembelajaran ekonomi adalah solusi dalam mengokohkan paham ekonomi Pancasila pada hati, pikiran dan tidakan anak bangsa. Kompetensi yang harus dicapain meliputi tiga ranah, yaitu: Pertama. Ranah kognitif mengacu pada Taksonomi Bloom meliputi: mengingat (C1) memahami (C2), mengaplikasi (C3), menganalisis (C4), mengevaluasi (C5), dan menciptakan (C6). Orientasi pada ranah kognitif adalah upaya mewujudkan kemampuan berpikir rasional, kritis dan terbuka serta berpandangan luas ditandai adanya kemampuan menelaah secara kritis, rasional, objektif dan visioner setiap teori dan peristiwa ekonomi yang terintegrasi dengan nilai ke-Tuhanan dan tanggung jawab sosial baik di lingkungan sekolah maupun di lingkungan masyarakat.

Kedua. Ranah afektif mengacu pada Taksonomi Krathwohl, meliputi: penerimaan, tanggapan, penghargaan dan pengorganisasian. Orientasi pada ranah afektif pembelajaran ekonomi berwawasan Pancasila adalah untuk menanamkan perasaan, emosi dan sikap positif terhadap materi dan peristiwa ekonomi yang ditandai adanya kepedulian, penghayatan dan rensponsif yang terintegrasi dengan nilai ke-Tuhanan dan tanggung jawab sosialbaik lingkungan sekolah maupun di lingkungan masyarakat. Ketiga. Ranah psikomotor mengacu pada Taksonomi Simpson, meliputi persepsi, kesiapan, membiasakan, mahir, dan menjadi gerakan orisinal. Orientasi ranah psikomotor dalam pembelajaran ekonomi berwawasan pancasila adalah melatih agar berpola tindak produktif, ditandai dengan adanya kemauan, keterampilan, keteladanan dan keuletan dalam mengimplementasikan teori ekonomi yang terintegrasi dengan nilai ke-Tuhanan dan rasa tanggung jawab sosial, baik di lingkungan sekolah maupun di lingkungan masyarakat. Untuk lebih jelasnya pemetaan kompetensi pembelajaran dapat diperhatikan dalam diagram berikut. 


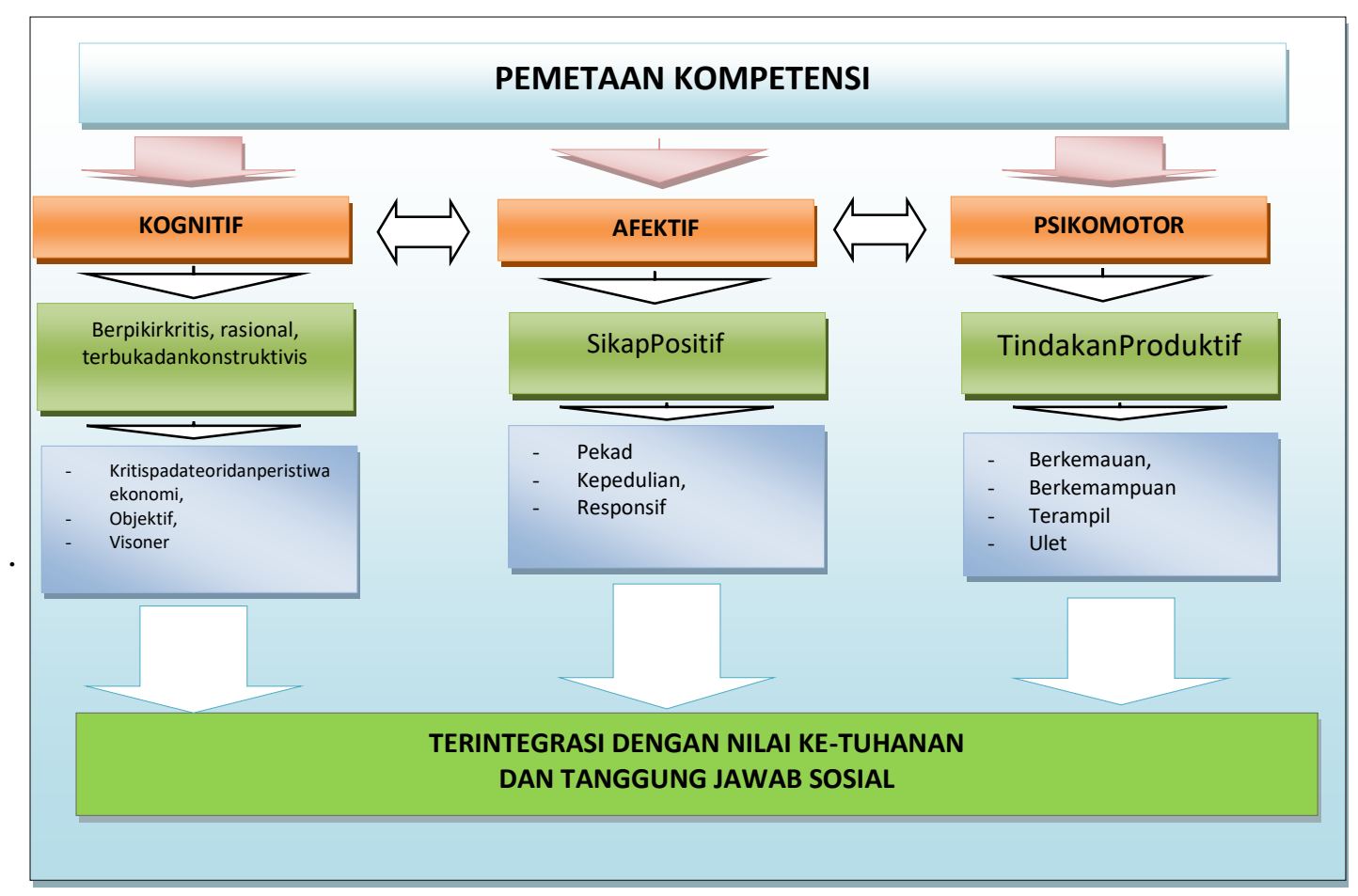

\section{Pendekatan PembelajaranEkonomi}

Ilmu ekonomi adalah bagian dari ilmu terapan dan pembahasannya berkaitan dengan perkembangan kehidupan sosial, sebab ilmu ekonomi adalah salah satu cabang dari disiplin ilmu sosial. Oleh karena itu, guru ekonomi disamping dituntut menguasai konsep ilmu ekonomi, juga dituntut untuk mengetahui dan mampu menerapkan berbagaipendekatan pembelajaran ekonomi, baik pendekatan deduktif maupun pendekatan induktif. Menurut Alfred Marshall yang dikutip oleh Mubyarto (1981) ilmu ekonomi diibaratkan dengan ilmu dua kaki (kanan dan kiri) untuk berjalan. Artinya jika hanya menggunakan satu pendekatan pembelajaran yang berpedoman pada buku teks (deduktif) maka pencapaian tujuan pembelajaran ekonomi bewawasan pancasilan akan sulit tercapai, oleh karena itu juga harus menggunakan pendekatan induktif yaitu pembelajaran ekonomi harus ditekankan pada pemahaman tentang fakta-fakta empiris yang terjadi dilingkungan sosial atau terjun langsung (observasi) pada peristiwa ekonomi.

Pendekatan induktif dalam hal ini berupa pembelajaran berbasis masalah dan kontekstual. Misalnya menjadikan bahan pembelajaran ekonomi tentang permasalahan ekonomi yang kita saksikan secara langsung maupun tidak langsung, baik dalam skala makro maupun dalam skala mikro. Skala makro, masalah ekonomi dapat dilihat dari berbagai perubahan kebijakan-kebijakan ekonomi yang memiliki implikasi langsung terhadap kehidupan sosial masyarakat. Demikian halnya dalam skala mikro, masalah ekonomi sering menjadi wacana yang tidak pernah selesai untuk dibicarakan bahkan telah menjadi diskursus oleh berbagai kalangan seperti tentang masalah pemenuhan kebutuhan rumah tangga. 


\section{KESIMPULAN}

Akhir-akhir ini Indonesia mengalami pertumbuhan ekonomi yang signifikan, namun pertumbuhan tersebut hanya dinikmati oleh segelintir orang. Pembangunan yang tidak berkeadilan disebabkan belum diimplementasikanya secara optimal sistem ekonomi Pancasila, baik oleh masing-masing pelaku ekonomi (mikro) maupun oleh pemerintah (makro). Secara sistem ekonomi Pancasila dirumuskan menjadi beberapa komponen sistem yang saling berkaitan antara yang satu dengan yang lainnya. Sila pertama dan sila kedua merupakan dasar/input setiap aktivitas ekonomi yang dirumuskan dengan etika ketuhanan dan kemanusiaan. Sila ketiga dan sila keempat merupakan metode/proses/cara kerja yang dan dirumuskan melaluiazaskekeluargaan dan nasionalisme. Sila kelima merupakan tujuan/output dari ekonomi pancasila dirumuskan dengan keadilan sosial ekonomi yang adil dan merata bagi seluruh rakyat Indonesia.

Instrumen kunci untuk menanamkan nilai-nilai ekonomi Pancasila pada pikiran, hati dan tindakan anak bangsa adalah dengan mengimplikasikannya kedalam pembelajaran ekonomi. Selama ini pembelajaran ekonomi di sekolah menengah cenderung bebas nilai (free value) Pancasila dan bersifat parsial. Kompetensi pembelajaran ekonomi Pancasila pada ranah kognitif lebih menekan adanya pola pikir yang rasional, kritis, berpndangan luas dan visioner. Pada ranah afektif ditinjau dari adanya persaaan, emosi dan sikap positif. Sementara pencapaian ranah psikomotor ditinjau dari pola tindak produktif. Secara keseluruhan kompetensi pembelajaran ekonomi Pancasila baik pada ranah kognitif, afektif maupun ranah psikomotorik harus terintegrasi dengan nilai ketuhanan dan tanggung jawab sosial.

Demi memudahkan pencapaian kompetensi pembelajaran adalah dengan menggabungkan pendekatan deduktif-induktif, sehingga pembelajaran ekonomi tidak hanya berpedoman pada buku teks (teks book), tetapi harus menghubungkan antara materi pokok dengan peristiwa ekonomi yang terjadi baik di lingkungan sekolah maupun di lingkungan masyarakat, yaitu melalui pembelajaran ekonomi berbasis masalah (problem basis learning)yang bersifat kontekstual (contextual).

\section{DAFTAR PUSTAKA}

Anderson, L. W. \& Krathwohl, D. R. 2000. A Taxonomy for $\backslash$ Learning, Teaching, and Assessing: A Revision of Bloom's Taxonomy of Educational Objectives. Allyn \& Bacon

Bank Dunia. 2004. Ketimpangan Semakin Melebar: Aku Akhiri Ketimpangan Untuk Indonesia. Australian Aid.

Bertens, K. 2000. Pengantar Etika Bisnis. Yogyakarta: Penerbit Kanisius.

Deliarnov. 2012. Perkembangan Pemikiran Ekonomi. Jakarta: Rajawali Perss.

Depdikbud. 1997. Kamus Besar Bahasa Indonesia.

Mubyarto. 1981. Ekonomi Pancasila. Yogyakarta: BPFE.

---------- 2004. Bagaimana Belajar Ilmu Ekonomi. Makalah disajikan dalam Seminar Bulanan ke-18 FEP UGM. 6 Juli 2014.

--------- 2004. Pendidikan Ekonomi Kita. Pusat Studi Ekonomi Pancasila: Universitas Gajah Mada

Nirbito J.G. 2005.Tanggung Jawab Sosial Dunia Bisnis (Strategi implementasi dan Tantangan Pendidikan Ekonomi). Universitas Negeri Malang (UM). 
Kratrwthol, D. R. 1964. Taxonomy Edacation Objective: Hand Book II, Affective Domain. New York: David McKay.

Soepriyatno. 2008. Nasionalisme \& Kebangkitan Ekonomi. Jakarta: INSIDe Perss.

Sri-Edi Swasono. 1992. Kemandirian Ekonomi: Menghapus Sistem Ekonomi Subordinasi Membangun Ekonomi Rakyat. Soft copy:Pdf.

Syaiful Sagala \& Darmayanti Lubis. 2011. Praktik Etika Pendidikan di Seluruh Wilayah NKRI. Bandung: Alfabeta.

Wahjoedi. 2015. Pendidikan Ekonomi: Berkarakter Nilai-Nilai Pancasila. Universitas Negeri Malang (UM).

Qudhariyanthi. 2014. dalam blogspot.co.id/ 2014/01/taksonomi. html?m=1. (diakses 09 Desember 2017). 